\title{
Developing English Printed Material on Theme of Plant for Early Young Learners at Paud Terpadu Joy Kids Makassar
}

\section{Nur Hilaila ${ }^{1}$, Kamsinah ${ }^{2}$, Sitti Nurpahmi ${ }^{3}$}

English Education Department, Universitas Islam Negeri Alauddin Makassar, Makassar, Indonesia

$$
\begin{array}{l|l}
\text { Q } & \text { } 1 \text { Nhilalia98 @gmail.com } \\
\text { Q } & \text { 2 kamsinah@uin-aluddin.ac.id } \\
\text { Q } & 3 \text { Sitti.nurpahmi@uin-alauddin.ac.id }
\end{array}
$$

\section{ABSTRACT}

Based on a preliminary study conducted in PAUD Terpadu Joykids Makassar, it was found that the material provided for students in introducing English vocabulary based on theme is still limited. In this case, the researcher intended to develop thematic English material for students. This study was Research and Development adapting ADDIE model that consists of Analysis, Design, Development, Implementation and Evaluation. In developing the material the researcher concerned on developing "plant" theme material. There were 1 teacher, 2 experts and 20 students involved in this research. This study found out the need of students at PAUD Terpadu Joykids over English material. The data of students need then become the inventory need in designing and developing the material. Moreover, the material consisted of English vocabulary integrated with the theme, number, picture, simple sentence, and art work.

\section{KEYWORDS:}

Developing English Printed Material; Early Young learners;

Plant

\section{Introduction}

English material is one of the components in English learning and teaching process. The first role of the material is to provide opportunities for learning (Ahmed, 2017). Learning opportunity consists of materials and all those activities both within and outside classroom which introduce language to the learners. The materials also provide learners chance to practice what has been learned. Thus, the existence of English material supports the effectiveness of the learning and 
teaching process. Similar to IImiah \& Nur (2018), they state that English material is one of the crucial component in conducting English language teaching and learning. It is utilized as the source that provides knowledge and activities that lead the students to comprehend and drill their skill in English. Moreover, it is used to control learning and teaching process handled by the teacher.

Although English material becomes the crucial component in conducting learning and teaching process, it is not well provided enough in every schools. The fact above is the result of the wisdom taken by Ministry of Education and Culture for education curriculum 2013 that English in kindergarten and elementary school is not a compulsory subject for students. One of the kindergartens that holds this wisdom is PAUD Terpadu Joy Kids Makassar. In this research, the researchers has conducted a preliminary study on June $25^{\text {th }} 2019$ and it is found that they use "Citra TK (learning magazine)" as the source to learn English which is provided in various themes. In addition, the material concerns on religion and moral value, motoric, cognitive, social-emotional and literacy. For the literacy itself, it consists of English and Bahasa. Unfortunately, the magazine contains only one page for English material and the other worksheets and activities are written in Bahasa.

The situation of English learning process in PAUD Terpadu Joy Kids as what has been discovered is contrast with some theories of language acquisition and characteristics of young learners especially for language learning. The age of 3 to 5 years old is called as the sensitive period or golden moment for children to study a language (Olpinska, 2015). In other words, early young learners still depend on language acquisition, so that the process of acquiring new language will be more successful than at later age. In addition, it is crucial to use pictures in describing an item to early young learners. Throughout the pictures young learners will easily know how the item looks like. Also, they will be able to acquire a true understanding of a thing. Thus, it is crucial to provide students material that consist of some interesting pictures that represent the word.

From the point above, the researcher decides to develop English material theme by providing colorful pictures and some various activities for students that aim to fulfill their need and support them in acquiring new language. The material later will be developed into some interesting themes. Those are My Self, 
Environment, Plant, Animal, and Occupation. However, this research will only focus on supporting young learners' vocabulary mastery of plant.

\section{Method}

In this research, the researcher uses Research and Development (R\&D) method. R\&D is defined as a research design that involves the classroom problems, studying recent theories of educational product development, developing the educational products, validating the product to experts, and field testing the product (Latif, 2012). Moreover, the researchers use the ADDIE model as the material development model. ADDIE stands for Analysis, Design, Development, Implementation, and Evaluation. However, in this research, the implementation is not included.

The research takes place in PAUD Terpadu Joy Kids. The participants are selected based on Purposive sampling in order to conduct data collection. Therefore, this research employed multiple data sources by inviting 20 learners, 1teacher of PAUD Terpadu Joy Kids and 2 experts from English Education Department and Islamic Early Childhood Education.

To obtain the data from the subjects, the research employs several instruments such as interview guidelines, document (syllabus used in PAUD Terpadu Joy Kids and the existing material) and validation checklist.

The data collected in this research is analyzed qualitatively and quantitatively. The first the data is analyzed qualitatively based on Mills and Gay (2016). The steps are as follow; Reading / Memoing (the researchers read the transcripts and write notes as well as underline the issue or section that seems crucial in order to obtain the initial sense of the data), Describing (This phase involves development through and comprehensive descriptions of the participants, the setting, and the phenomenon studied to convey the rich complexity of the research), and Classifying (The researchers break down the data into smaller units, determined their import, and put the pertinent units together into more general patterns).

After that the data is analyzed quantitatively. In this phase, the researcher evaluates by using distributing validation checklist to the experts. The validation checklist is constructed based on the concept of likert scale. It contains yes or no answer for each response of the question. After collecting the result of the 
validation checklist, the researchers will calculate the data manually by using the formula below:

$$
\mathrm{P}=\frac{f}{n} \times 100 \%
$$

Symbols:

Figure 1 : Score Formula

$\mathrm{P}=$ Percentage

$\mathrm{F}=$ The Frequency of The Responses

$\mathrm{N}=$ The Ideal Score Total

$100 \%=$ Constant number

The result of the presentation will present the quality of the product which is described in one of five ranges, as follows:

\begin{tabular}{|l|l|}
\hline \multicolumn{1}{|c|}{ Grade Scale } & \multicolumn{1}{c|}{ Verbal Scale } \\
\hline $81-100$ & Very Good \\
\hline $61-80$ & Good \\
\hline $41-60$ & Sufficient \\
\hline $21-40$ & Bad \\
\hline $0-20$ & Very Bad \\
\hline
\end{tabular}

Table 1. Rating Scale

\section{Finding}

The result of the research is in the form of data analysis. The data is analyzed quantitatively and qualitatively. For the qualitative data, the researcher conducts an interview with the teacher and document analysis. The first finding is the needs of the early young learners at PAUD Terpadu Joy Kids Makassar for English printed material on theme of Plant.

More points to elaborate from these needs are as follows; Learning Ability (It is found out by analyzing Language information gathered through the interview. Language information refers to present situation of student's English skill. It presented how far is students' skill and comprehension for English. The data indicated that students only know how to mention the word by imitating how their teachers pronounce it. Moreover, they cannot write it), and Learning Priority 
(Obtained by analyzing the data gained from teacher interview on the Personal information. It indicated that students are taught English by recognizing the themebased vocabulary. One of the themes presented for them is Plant theme. In addition the data obtained from the Language learning need information displayed that the material presented should consist of vocabulary, number, simple sentence and art).

There is also found learning needs consist of; Students Learning Problems (Obtained from the interview shows that students learning problems analyzed from learner's lack information. It is drawn that students had problems with their learning material. Learning material provided is monotonous for them. As the result, they have less interest in learning. Moreover, based on the document analysis, it shows that the material consisting only some colorful page. For the activities, there are only limited activities that may support students in learning the topic along with the English), students learning preferences (According to the learners need information obtained from interview, students prefer to learn concrete things rather than the abstract one. Hence, during the learning process it is crucial to present a picture or use realia to teach the students. Moreover, they prefer to learn something attractive for them. There should be various activities and interesting picture presented for them), and students learning style (Obtained by analyzing information from the interview. Based on the environmental situation it is found that the teacher utilize the media and things surround the students so that the students may learn by playing, using pictures, and getting involved in learning and teaching process. Moreover, they feel more enjoyable when the activity is not only conducted by sitting still in the classroom but also allow them to go out and learn).

\section{Discussion}

In this research, the researcher designs a syllabus which will facilitate the researchers in designing and developing the English printed material. It is designed based on steps elaborated in Ministerial regulation of Ministry of Education and Culture no 1462014 on Kindergarten Curriculum, the steps could be seen as follows; make list of theme for one semester (The researcher needs to select some themes that will be contained in the syllabus. The suitable themes for kindergarten 
have been providing in the school syllabus based on the curriculum. Then, the researcher selects some themes in the existing syllabus that will be developed), determine the time allocation of learning process (The researcher should determine time allocation for each theme that will be taught. Based on the existing syllabus, the researchers find out the time allocation for each theme), determine the basic competence on each theme (The researchers determined the basic competence on each theme based on the syllabus of the kindergarten), select and arrange the theme (It is regarding to some principal; a theme selected is the most common topic for kindergarten students, a theme is arranged gradually by considering the difficulty level, it should be started by the simple one to the difficult one, a theme selected by considering students' interest, a theme consists all the aspects of students growth. After observing the themes provided in the existing syllabus. The researchers found out five themes that could be developed regarding the principals above, such as My-Self, Environment, Plant, Animal, and Occupation).

In this research, the researcher intends to develop the "Plant" theme and elaborates a theme into some theme subs and specifically divided each theme sub into some subs for each semester (In this research, the researcher develops a theme that is "Plant" theme. Based on the existing syllabus in PAUD Terpadu Joykids, this theme contains some subs of theme. However, the researchers concerns only on "Part of Fruit" theme sub and design the syllabus by adapting syllabus form of kindergarten in Ministerial Regulation. It contains some components such as theme/sub of theme, basic competence, indicator, learning activity, media/learning source, evaluation, duration. The prototype syllabus designed by the researchers can be seen as follows:

\begin{tabular}{|c|c|c|c|c|c|c|}
\hline $\begin{array}{c}\text { Theme/ Sub of } \\
\text { Theme }\end{array}$ & Basic Competence & Indicator & $\begin{array}{l}\text { Learning } \\
\text { Activity }\end{array}$ & $\begin{array}{c}\text { Media/ Learning } \\
\text { Source }\end{array}$ & Evaluation & Duration \\
\hline $\begin{array}{l}\text { Plant } \\
\text { "Parts of Fruit " }\end{array}$ & $\begin{array}{l}\text { understanding the } \\
\text { expressive language } \\
\text { skill (expressing } \\
\text { language skill } \\
\text { verbally and non- } \\
\text { verbally) }\end{array}$ & $\begin{array}{l}\text { 3.11.1 Imitating the } \\
\text { pronunciation of } \\
\text { the English } \\
\text { Vocabulary } \\
\text { correctly }\end{array}$ & $\begin{array}{l}\text { "Listen and } \\
\text { Say" Teacher } \\
\text { show picture } \\
\text { and } \\
\text { pronounce } \\
\text { the } \\
\text { vocabulary }\end{array}$ & $\begin{array}{l}\text { Learning material } \\
\text { Pictures } \\
\text { Realia } \\
\text { Teachers } \\
\text { voice }\end{array}$ & $\begin{array}{l}\text { Observati } \\
\text { on }\end{array}$ & $15 \mathrm{~m}$ \\
\hline
\end{tabular}






Table 2: Prototype Syllabus

Based on the result of students' need analysis, the development will concern on "Plant" particularly on "Part of Fruit" theme sub. Moreover, the developed 
material will contain various activities that more concern on introducing English Vocabulary based on theme to the students. All the activities included are organized based on several aspect of learning material namely morality and religion, social and emotional, cognition, Language, physical, and art.The elaboration of each aspect and its learning activity can been as follows;

\section{Morality and Religion}

According to Ministerial Regulation of Education and Culture (2015), one of the regulations in childhood education is the aspect of morality and religion. It requires the teacher to guide them about morality and religion values. Their understanding of the values is obtained from their learning activity. In interview section, the teacher of PAUD Terpadu Joy Kids explained of how they deliver the morality and religion aspect in the class. It is stated that the aspect is delivered implicitly. During the class, the teacher will observe how the students behave in the class whether they implement morality and religion aspect. Sometimes the teacher found that the students implement moral aspect through the interaction among the students and even teacher during the class for example they pay attention to people who explain or talk to them.

While for the religion aspect, can be seen when the students started their learning process by praying. In this research the researcher provides learning activity regarding morality and religion aspect. The researcher attempts to show them directly by giving example related to phenomenon around them. Hence they will be more easily to understand this aspect. It includes; what do you think? (Good or Bad) (In this learning activity, the material is provided in form of a worksheet. It leads the students to understand the examples of good behavior that they usually find in their daily life. Throughout the worksheet, there will be some illustrations of good behavior and bad behavior that commonly happen in daily life. Since the developed material concerned on "Plant theme" so, the illustrations will refers to good behavior and bad behavior over the plant. One example could be a picture of a kid who is planting a flower and another one is a picture of a kid who is step on the flower. Then the students are asked to determine which illustration that represent the good behavior and which one is the bad one. They may draw the symbol of good $(\sqrt{ })$ if they determine it as a good behavior and they draw symbol 
of bad ( $x$ ) if they think the illustration is as a bad behavior. In addition, the researcher also provides caption for each illustration. The caption itself contain several vocabularies refers to plant. Therefore, students may improve their vocabulary), and give the color! (The students are presented one of the name of Allah. They are asked to give color to it. Under the name the researchers attached the name of Allah in English and Indonesian. This activity might help students to recognize one of the Name of Allah)

\section{Physical-Motoric}

During students' growth they will be encountered improvement for each stage of growth they pass. One of the improvements is their kinesthetic improvement. The improvement refers to ability to utilize their part of body. Hence, in developing the material the researchers should provide learning activity that support their kinesthetic improvement.

It engages the students to involving their parts of body during their learning experience. Therefore, the researchers provided activities as follows; cut and stick (The students are provided pictures of uncolored fruit parts that are separate one another. Hence, the students are asked to arranged fruit parts and be organized well so that the fruit could be seen clearly. However, again the students need to cut the picture and stick it when organizing it. Moreover, the researchers also provides vocabulary for each part of the plant in order to support the students in learning vocabulary), and solving puzzle (In this activity, the students are lead to know more about fruit vocabulary by solving puzzles. There will some pictures of fruit however, the pictures are not served complete, and they lose some parts. Then under the uncompleted pictures there are some puzzles in form of several squares that will complete the losing parts of the fruit picture. Students have to choose which shape that suit for each uncompleted picture. During solving the puzzle first thing that students need to do is recognizing the uncompleted pictures by reading the vocabulary on it. When the students have recognized the fruit in the picture, they may easily choose the correct puzzle to complete the picture). 


\section{Cognitive}

Cognitive aspect stimulates the students to use and improve their thinking ability during their learning experience. Hence, the researchers provided them activities that require students' thinking ability.

In the material development, the students involve their thinking ability when they attempt to solve the problem or do something based on the instruction given. The activities such as; fruits grouping (the students have to classify which fruit tastes sweet and which fruit tastes sour. The students will draw emoticon smile for sweet fruit and will draw sad emoticon for sour fruit. Before doing their task, the students are introduced two vocabulary of fruit taste such as sweet and sour), fruits counting (The students are lead to recognize the same fruit and count them. After counting the fruits the students will match the fruit with the number that has been provided by drawing line to connect the fruits with the correct number. Here, the students will obtain additional vocabulary of number), dots connecting (the researchers intends to stimulate students' ability in writing by providing them some fruits vocabulary in form of separate dots. Students' task is to rewrite the vocabulary by connecting the dots so the vocabulary can be read well. Here while doing the task the students may learn how to write the vocabulary, recognize the letter for each word and understand the vocabulary).

\section{Social Emotional}

In this part, the activity intends to stimulate students in building their character. The researchers prepares a worksheet where the students are able to decide what they have to do when they are facing a particular situation.

After doing the task the students are expected to be students with good character. They know how to behave to their selves, other people, even to the other creatures like animal, plant or even unloving things. The task here is called what will you do? In this activity, the researchers provides the students a picture along with description to describe a condition. The students then asked to choose what actions they will take when they face the situation the pictures are not well arranged. To support students in learning vocabulary the researchers gives a simple caption for each picture that consists of some vocabularies. 


\section{Language}

It refers to students' ability in in using language skill. Hence, the researchers has prepared learning activity intended to encourage the students to recognize sound and words. Moreover, it intends to stimulate students to speak and even write simple words.

The activity are as follows; listen and say (The students are showed several pictures of fruit along its name. Then the teacher will pronounce each fruit one by one. After the teacher mentions one fruit students have to follow her. Students and teacher do it until all the fruits are pronounced well. This activity intends to introduce vocabulary of fruit to the students. Moreover, it also attempts to encourage students to practice speaking English, Who am I? (The students are expected to guess the name of fruit. In the worksheet the researchers has provided some pictures of fruits then students have to guess the name of its picture. The teacher will ask the students to mention the name of fruit by pointing one of the picture), Spell its name! (The students are asked to spell the vocabulary of fruit by following the teacher. While the teacher will spell the word clearly in order that the students can imitate her), Arranging Letters (In this activity the students are asked to re-arrange some letters into a correct vocabulary of fruit. To stimulate the students the picture of each word will be displayed), and what is your favorite fruit? (The students are served a simple conversation in English talking about favorite food. The students will learn how to express their favorite fruit in English and practice to talk with their friends).

\section{Art}

In this part, the researcher provides students activity that let the students to express their creativity and build their confidence. The activities can be seen as follows; Sing a song (In this activity, the students are given lyrics of an English song that contains of vocabulary related to fruit. Then they will listen to the song and looking at the lyrics after that the teacher will replay the song and all the students are asked to sing together), and draw me !(In this activity the students are asked to draw their favorite fruit. This activity attempts to let students' creativity and confidence build up. The researcher leaves a simple question on the worksheet asking them in English. The question will be "what is your favorite food?" well the 
question is followed by the translation to facilitate the students in understanding the question. Also the researchers gives picture as example and instruction to answer the question by drawing their favorite fruit).

\section{The Evaluation Result of English Printed Material on Theme of Plant for Early Young Learners at PAUD Terpadu Joy Kids Makassar}

This is the last phase conducted by the researcher based on ADDIE model. In this phase, material developed will be carefully considered in order to decide it had been appropriate or not. The evaluation will be conducted in three different kinds of evaluation.

Those are self-evaluation which will be done by the researcher herself, peerevaluation which will be conducted by the other researchers, and last is expert evaluation that definitely will be handled by experts in this case are the teachers of PAUD Terpadu Joykids. In this research, the researchers developed an English material for students at PAUD Terpadu Joykids.

In self-evaluation, the researcher starts the research by investigating students' need over the material. The material concerned on "Plant" theme based on the need analysis result. The theme is selected after the researchers conducted a preliminary study and need analysis. Based on the preliminary study it is found that there are some themes provided and one of those is "Plant" theme. While based on need analysis conducted by interviewing the teacher and observing some documents from school. The documents are previous material, syllabus, weekly lesson plan, and daily lesson plan. It is found that material for "plant" theme being used at school is needed to develop. Moreover, the theme selected concerned on "parts of fruit" theme sub.

Continuing into the peer evaluation, it is the process of determining how the developed material is and is conducted by the other researchers of this research. There are four researchers who will evaluate the material. They utilized a validation checklist constructed based on some theories and contained some aspects. According to the instrument the researchers will identify the relevancy of the material, the thematic material, the learning activities, the skill and competence, the teachers' role toward the material, the learners' role toward the material, the 
existing of self-development program, and the appearance of the material will be. The result of the peer evaluation indicated that the developed material is good enough but still need to be revised. It had been constructed well by providing colorful pictures related to the theme. In addition the learning activity also had been presented in various model regarding the aspect in kindergarten curriculum. However, there are some suggestions from the other researchers. The first researcher suggests that the researchers should be careful with the appearance of the material. The researcher should consider how the instructions presented. It included the font type, model and how to differentiate each instructions to make it more interesting and easy to understand. Moreover, the second researcher along with the third and fourth researchers only suggested that adding the main competence and basic competence is crucial on the worksheet.

\begin{tabular}{|l|l|l|}
\hline Aspect & Indicator & Items \\
\hline $\begin{array}{l}\text { The relevance of the } \\
\text { material (Tomlinson, 2013) }\end{array}$ & $\begin{array}{l}\text { The appropriateness of the material for } \\
\text { childhood education in introducing } \\
\text { English } \\
\text { The appropriateness of the material } \\
\text { toward the students' need } \\
\text { The appropriateness of English material } \\
\text { toward the age of students }\end{array}$ & 30 \\
\hline $\begin{array}{l}\text { The thematic material to } \\
\text { introduce “Environment" in } \\
\text { English (Soni, 2015) }\end{array}$ & $\begin{array}{l}\text { The appropriateness of Environment } \\
\text { theme for childhood education } \\
\text { The Environment theme as a part of } \\
\text { students' interest } \\
\text { The influence of Environment theme for } \\
\text { students' English learning }\end{array}$ & 30 \\
\hline $\begin{array}{l}\text { The learning activities in the } \\
\text { developed material (Soni, } \\
\text { 2015) }\end{array}$ & $\begin{array}{l}\text { The variety of activity in the developed } \\
\text { English material }\end{array}$ & 30 \\
\hline
\end{tabular}




\begin{tabular}{|c|c|c|}
\hline & $\begin{array}{l}\text { The influence of English material toward } \\
\text { students' active participation } \\
\text { The influence of English material for } \\
\text { students to practice English }\end{array}$ & 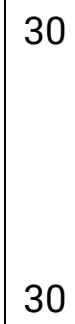 \\
\hline $\begin{array}{l}\text { The skill and the } \\
\text { competence in the } \\
\text { developed material } \\
\text { (Suyanto, 2014) }\end{array}$ & $\begin{array}{l}\text { The influence of English material toward } \\
\text { students English skill development } \\
\text { The influence of English material to } \\
\text { provide thematic vocabulary }\end{array}$ & 50 \\
\hline $\begin{array}{l}\text { Teachers' role toward the } \\
\text { developed material } \\
\text { (Tomlinson, 2013) }\end{array}$ & $\begin{array}{l}\text { The use of the developed material as } \\
\text { teaching reference for teacher } \\
\text { The easiness of English material to be } \\
\text { used by the teacher } \\
\text { The use of English material in evaluating } \\
\text { students skill development }\end{array}$ & 30 \\
\hline $\begin{array}{l}\text { The learners' role toward the } \\
\text { developed material } \\
\text { (Tomlinson, 2013) }\end{array}$ & $\begin{array}{l}\text { The influence of English material in } \\
\text { students' social interaction } \\
\text { The influence of English material in } \\
\text { creating interactive condition in the } \\
\text { classroom }\end{array}$ & 50 \\
\hline $\begin{array}{l}\text { The existing of self } \\
\text { development program in } \\
\text { material (Ministry, 2015) }\end{array}$ & $\begin{array}{l}\text { The appropriateness of English material } \\
\text { the whole aspect in childhood education } \\
\text { curriculum }\end{array}$ & 0 \\
\hline $\begin{array}{l}\text { The appearance of the } \\
\text { developed material (Piaget, } \\
\text { 2015) }\end{array}$ & $\begin{array}{l}\text { The attractiveness of the developed } \\
\text { material for students }\end{array}$ & 40 \\
\hline
\end{tabular}




\begin{tabular}{|l|l|l|}
\hline \multirow{2}{*}{\begin{tabular}{l|l|} 
The appropriateness of the input (picture, \\
vocabulary, activity) for students \\
The encouragement of the input for \\
students to learn English
\end{tabular}} & 0 \\
\hline Total & 510 \\
\hline
\end{tabular}

Table. 3 Peer Evaluation Result

$$
P=\frac{510}{800} \times 100 \%=63,75 \%(\text { Good })
$$

Expert validation is the last process where the developed material is validated by the experts in order to find out whether the material has been appropriated enough to use. In this research there are two experts who validated the material. Both of the experts are the lecturer of Early Young Learners Islamic Education Department and the lecturer of English Education Department at Alauddin State Islamic University of Makassar. The result of the first validation process indicated that the researchers should provide step to conduct the learning process in delivering the developed material. After that, the researchers included the learning step suggested in the first validation process. Then, after adding the learning steps, the experts then conducted the second validation. It is revealed that the material had been good but still need to be revised. The expert suggested that the material should include all the growth aspect specifically the social and emotional aspect and should consider the level of the task with students' age.

\begin{tabular}{|l|l|l|}
\hline Aspect & Indicator & Items \\
\hline $\begin{array}{l}\text { The relevance of the } \\
\text { material (Tomlinson, 2013) }\end{array}$ & $\begin{array}{l}\text { The appropriateness of the material } \\
\text { for childhood education in } \\
\text { introducing English } \\
\text { The appropriateness of the material } \\
\text { toward the students' need } \\
\text { The appropriateness of English } \\
\text { material toward the age of students }\end{array}$ & 30 \\
\hline
\end{tabular}




\begin{tabular}{|c|c|c|}
\hline $\begin{array}{l}\text { The thematic material to } \\
\text { introduce "Environment" in } \\
\text { English (Soni, 2015) }\end{array}$ & $\begin{array}{l}\text { The appropriateness of Environment } \\
\text { theme for childhood education } \\
\text { The Environment theme as a part of } \\
\text { students' interest } \\
\text { The influence of Environment theme } \\
\text { for students' English learning }\end{array}$ & 40 \\
\hline $\begin{array}{l}\text { The learning activities in the } \\
\text { developed material (Soni, } \\
\text { 2015) }\end{array}$ & $\begin{array}{l}\text { The variety of activity in the } \\
\text { developed English material } \\
\text { The influence of English material } \\
\text { toward students' active participation } \\
\text { The influence of English material for } \\
\text { students to practice English }\end{array}$ & 30 \\
\hline $\begin{array}{l}\text { The skill and the } \\
\text { competence in the } \\
\text { developed material } \\
\text { (Suyanto, 2014) }\end{array}$ & $\begin{array}{l}\text { The influence of English material } \\
\text { toward students English skill } \\
\text { development } \\
\text { The influence of English material to } \\
\text { provide thematic vocabulary }\end{array}$ & 50 \\
\hline $\begin{array}{l}\text { Teachers' role toward the } \\
\text { developed material } \\
\text { (Tomlinson, 2013) }\end{array}$ & $\begin{array}{l}\text { The use of the developed material as } \\
\text { teaching reference for teacher } \\
\text { The easiness of English material to } \\
\text { be used by the teacher } \\
\text { The use of English material in } \\
\text { evaluating students skill } \\
\text { development }\end{array}$ & 40 \\
\hline
\end{tabular}




\begin{tabular}{|c|c|c|}
\hline $\begin{array}{l}\text { The learners' role toward the } \\
\text { developed material } \\
\text { (Tomlinson, 2013) }\end{array}$ & $\begin{array}{l}\text { The influence of English material in } \\
\text { students' social interaction } \\
\text { The influence of English material in } \\
\text { creating interactive condition in the } \\
\text { classroom }\end{array}$ & 50 \\
\hline $\begin{array}{l}\text { The existing of self } \\
\text { development program in } \\
\text { material (Ministry, 2015) }\end{array}$ & $\begin{array}{l}\text { The appropriateness of English } \\
\text { material the whole aspect in } \\
\text { childhood education curriculum }\end{array}$ & 0 \\
\hline $\begin{array}{l}\text { The appearance of the } \\
\text { developed material (Piaget, } \\
\text { 2015) }\end{array}$ & $\begin{array}{l}\text { The attractiveness of the developed } \\
\text { material for students } \\
\text { The appropriateness of the input } \\
\text { (picture, vocabulary, activity) for } \\
\text { students } \\
\text { The encouragement of the input for } \\
\text { students to learn English }\end{array}$ & 40 \\
\hline \multicolumn{2}{|l|}{ Total } & 550 \\
\hline
\end{tabular}

Table. 4 Expert Validation Result

$$
\begin{aligned}
P & =\frac{550}{800} \times 100 \% \\
& =68,75 \%(\text { Good) }
\end{aligned}
$$

\section{Conclusion}

The research is conducted in order to develop Plant theme English Material for Early young learners at PAUD Terpadu Joy Kids Makassar. It is started with need analysis by conducting interview with the teacher and observing some documents from the kindergarten including the syllabus, the lesson plan, and the existing material (Citra TK). The result of this process indicated students learning style and appropriated material These data becomes the foundation in designing and developing the English material.

The English material developed concerns on introducing Vocabulary related to Plant. The material is designed by including the six self development program 
(Morality and Religion, Social-Emotional, Cognitive, Physical-Motoric, Language, and Art) in learning activity. It contains vocabulary, number, phrase, simple sentence, and art. Moreover, it is presented in some colored pictures and various learning activity. Moreover the researchers provided barcode to support students in recognizing the vocabulary. The result of validation process indicates that the developed material has been appropriated enough to be implemented in Kindergarten.

\section{References}

Ahmed, S. (2017). Authentic ELT Materials in the Language Clasroom: An

Overview. Journal of Applied Languageand Language Research, 4(2), 181.

Ilmiyah, N., \& Nur, A. (2018). Developing Asking and Giving Information Materials

Dealing with 2013 Curriculum of SMP Eight Grade. Alauddin State Islamic University of Makassar.

Latif, M. A. (2012). Research Methods on Language Learning (An Introduction). Developing English Learning Material for Young Learners Based on Need Analysis at MTsN Model Makassar (Vol. 1). Malang: UM Press.

Mills, G. E., \& Lorraine, R. G. (2016). Educational Research Competencies for Analysis and Applications (11th Edition). United States of America: Pearson.

Ministry of Indonesia Education and Culture. (2015). The Regularity of Education and Culture Ministry of Indonesia Number 145 Year 2014 for Childhood Education Curriculum 2013.

Olpinska, M. (2015). Teaching Materials for English in The Primary Education also for the pre-school education. Uniwersytet Warszawski.

Piaget. (2015). Piaget's Stages of Cognitive Development. Boundless Psychology.

Soni, R. (2015). Theme Based Early Childhood Care and Education Programme. National Council of Educational Research and Training.

Suyanto, K. K. . (2014). English for Young Learners. Bumi Aksara.

Tomlinson, B. (2013). Developing Materials for Language Teaching (2nd Ed). United Kingdom: Bloomsburry. 